This article was downloaded by: [Tran, Hoai Anh]

On: 2 September 2008

Access details: Access Details: [subscription number 902117006]

Publisher Routledge

Informa Ltd Registered in England and Wales Registered Number: 1072954 Registered office: Mortimer House, 37-41 Mortimer Street, London W1T 3JH, UK

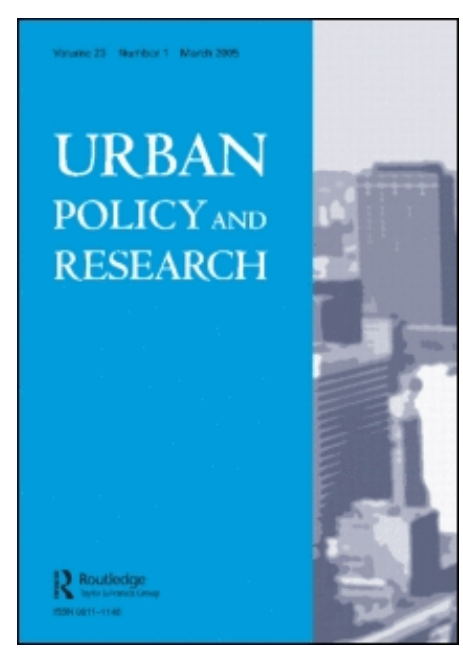

Urban Policy and Research

Publication details, including instructions for authors and subscription information:

http://www.informaworld.com/smpp/title content=t713449094

\title{
Caught between Plan and Market: Vietnam's Housing Reform in the Transition
} to a Market Economy

Hoai-Anh Tran a; Ngai-Ming Yip ${ }^{\text {b }}$

a University of Gothenburg, Gothenburg, Sweden ${ }^{b}$ City University of Hong Kong, Hong Kong, China

Online Publication Date: 01 September 2008

To cite this Article Tran, Hoai-Anh and Yip, Ngai-Ming(2008)'Caught between Plan and Market: Vietnam's Housing Reform in the Transition to a Market Economy',Urban Policy and Research,26:3,309 - 323

To link to this Article: DOI: $10.1080 / 08111140802301765$

URL: http://dx.doi.org/10.1080/08111140802301765

\section{PLEASE SCROLL DOWN FOR ARTICLE}

Full terms and conditions of use: http://www.informaworld.com/terms-and-conditions-of-access.pdf

This article may be used for research, teaching and private study purposes. Any substantial or systematic reproduction, re-distribution, re-selling, loan or sub-licensing, systematic supply or distribution in any form to anyone is expressly forbidden.

The publisher does not give any warranty express or implied or make any representation that the contents will be complete or accurate or up to date. The accuracy of any instructions, formulae and drug doses should be independently verified with primary sources. The publisher shall not be liable for any loss, actions, claims, proceedings, demand or costs or damages whatsoever or howsoever caused arising directly or indirectly in connection with or arising out of the use of this material. 
Urban Policy and Research,

Vol. 26, No. 3, 309-323, September 2008

Routledge

Taylor \& Francis Grou

\title{
Caught between Plan and Market: Vietnam's Housing Reform in the Transition to a Market Economy
}

\author{
HOAI-ANH TRAN* \& NGAI-MING YIP** \\ *University of Gothenburg, Gothenburg, Sweden \\ **City University of Hong Kong, Hong Kong, China
}

\begin{abstract}
The housing sector in Vietnam follows a 'gradualist' approach of transforming from a socialist system in which the state assumed effective control to a market-oriented system that the laws of supply and demand rule. Yet the long and winding transition within such a dual system produces inevitable contradictions between the state and the market as well as between the economic and the political institutions. This paper explores the dynamics of such interactions and contradictions in Vietnam's transforming housing system, employing Hanoi as a case study. The paper analyses the functioning and teething problems of the new housing market as well as the resurgence of the role of the state in solving the contradictions in the reform process.
\end{abstract}

内容摘要：越南的住房部门走了一条 “渐进” 的道路, 从国家实行有效控制的社会主义制度向遵 从供需法则的市场制度转型。但是, 转型的道路漫长曲折, 长期实行二元制度在国家和市场, 以 及经济制度和政治制度之间, 导致了一些不可避免的矛盾。本文以河内为例, 探讨越南住房制度 转型中互动的动力和矛盾, 分析新兴住房市场的作用和初级阶段的问题, 并说明在解决改革进程 中的矛盾的过程中, 国家的角色如何复苏。

KEY WORDS: Housing reform, transitional economy, Vietnam

\section{Introduction}

After decades of war and years of economic turmoil after unification, Vietnam embarked on economic reform, Doi Moi (which literally means renovation), in 1986 with a clear intention of lifting the country from economic crisis. The housing sector, which is perceived as a locomotive for economic development as well as a vital necessity for ordinary people, has been put at the centre of the reform. The housing sector in Vietnam has been transformed from a socialist system, in which the state had total control in terms of the supply and allocation, towards a market-oriented system dictated by the laws of supply and demand. However, housing reform in a transitional economy is not a straightforward planned move on the drawing board but a process that involves

Correspondence Address: Ngai-Ming Yip, City University of Hong Kong, Tat Chee Avenue, Hong Kong, China. Tel.: + 8522788 9366; Email: sayip@ cityu.edu.hk

0811-1146 Print/1476-7244 Online/08/030309-15 (C) 2008 Editorial Board, Urban Policy and Research DOI: $10.1080 / 08111140802301765$ 
complicated interactions between the state and the market. It is even more delicate in Vietnam as she aims to develop the reform within a largely intact political system dominated by the Vietnamese Communist Party. In addition, the road to market reform in transitional economies is, arguably, 'path dependent', and experience in Eastern Europe and China is unlikely to be able to be replicated in full in Vietnam. Cultural and institutional legacy would definitely affect the path of development. Likewise, a low level of industrialisation and urbanisation in Vietnam, compared with her ex-socialist comrades, would also make a big difference.

It is the aim of this paper to examine the urban housing reform in Vietnam in the last two decades. It will focus on the interactions and contradictions, brought along by the housing reform, between the state and the market, the commercial and social ambitions as well as the economic and the political goals. Against the backdrop of the changing role of the state in the development of housing policy and the creation of the housing market, this paper discerns Vietnam's efforts in striking a balance between economic development and social objectives and her struggle in forging the political will for reform against the pressure from the old bureaucracy and the conservative mindset.

The paper is divided into six sections. The section that follows the introduction is a descriptive account of reform experience in Eastern Europe and China which serves as the back cloth for subsequent discussions. The third section briefly reviews significant developments in the housing market in Vietnam whereas the fourth section explores the interactions between the state and the market. The fifth section focuses on the revitalisation issue of public housing and the incompatibility between a dedicated social ambition and a poor administrative capacity. The final section discusses the roles of the state in the development of the housing sector in transitional Vietnam, highlighting the achievements and the problems, its ambivalent approach and the legacy of the old system.

\section{Experience of Housing Reform in Eastern Europe and China}

With the economic system largely mirrored on a Soviet-type central planning system, housing in Vietnam before Doi Moi largely followed the East European housing model. Such model is described by Hegedüs \& Tosics (1996) as the exclusion of the market, the omission of housing costs from incomes, and the control of housing resources and distribution by state institutions. Vietnam, together with China, were the earliest reformers of the old socialist system. Yet it was the latecomers, Soviet Union and East European countries, which caught up fast with their wholesale embracement of the market economy. Starting with abrupt political reform, such countries replaced the old single party authoritative rule overnight by a multi-party democratic system of Western style. Such political change also necessitates a fully fledged move towards the creation of private ownership and the construction of a pluralist society (Hegedüs \& Tosics, 1998). On the one hand, complete privatisation of housing offers the quickest means in the creation of private ownership on a massive scale and this was achieved in such countries, either by transferring state ownership of housing to outside owners or via equal access vouchers, for free or at low cost, to sitting tenants (Gray, 1996). On the other hand, decentralisation of power from the centre to newly restructured local governments, though varied across countries in its extent, has resulted in the creation of independent power of the local governments in administering local urban and housing services (Hegedüs \& Tosics, 1998). 
Yet, the 'big-bang' approach adopted by the former Soviet Bloc encountered rather serious problems at the beginning. For instance, among the 17 countries in Central and Eastern Europe surveyed by Hamilton (1999), all of them experienced a drop in real GDP between 1990 and 1993 and all but three countries had hyperinflation at the same time (with inflation peaking at 10155 per cent in Ukraine). Such economic turmoil also created a negative impact on housing - national output of housing dropped substantially in the earlier years of reform, house prices rose much quicker than the increase in salaries which resulted in serious affordability problems (Renaud, 1995; Hegedüs \& Tosics, 1998). Yet, many of such problems were merely adjustment conflicts which would stabilise when the economy reached equilibrium (Hegedüs \& Tosics, 1998) and they did not deter the pace of privatisation in such transitional economies (Renaud, 1995). Fore-runners like Hungary and Albania were highly successful (96 per cent of home ownership in 1994 and 1998, respectively) and even the laggards such as Czech Republic (59 per cent in 2001) and Poland (55 per cent in 2000) also achieved a high home ownership rate by international standards (Stephens, 2005).

Concomitant with such temporary teething problems are other structural conflicts which have produced high costs for the society and the economy in these transitional economies. Many of such problems, manageable in the market economy of more advanced capitalist countries, would often become problematic in the transitional economies, owing either to cultural factors or the lack of 'technical means' in handling such conflict. For instance, in Hungary, 10 years after the reform, new owners, who acquired their homes in a give-away exercise of privatisation, still could not adjust to their new position in the market housing system and the corresponding responsibilities they have to take under the new regime (Hegedüs \& Tosics, 1998).

Despite the apparent similarities in the privatisation policy, Pichler-Milanovich (2001) instead argues against a unified model of housing reform in transition economies in Europe. Economic reforms in such countries exhibit initial evidence of 'path dependent' developments which are influenced by "historic and institutional factors before, during and after the socialist period-and current influence and policy 'know-how' of neighbouring EC countries" (Pichler-Milanovich, 2001, p. 176). Based on the observations on the development of the housing market in 15 Central and Eastern European countries in the 1990s, Scandinavian countries seem to have influenced the housing system in the Baltic countries, so were Southern Europe on south-east European countries and central European countries on Czech Republic. This also matches with the observations made by Tsenkova \& Turner (2004) on the size of the public housing sector in 15 transitional economies in 2001 with reference to the influence of Western and Northern European countries in the context of dichotomous unitary-dual housing regimes.

Despite such differentiation, common to most of the transitional economies are the withdrawal of supply side subsidies (at least the explicit subsidies), with Poland as an exception. Whilst Poland set up a new type of social housing operator with a corresponding increase in state investment in housing, all other transitional economies witnessed their supply side subsides being axed. Yet, worsening affordability has pushed most Central and Eastern European countries to introduce demand side subsidies of some kind to mitigate the problem of unaffordability, most of which are targeted at households on low incomes (Lux, 2003). Interestingly, countries that have developed more efficient or effective subsidies under the new regime were the countries which did worse in the pre-reform era (Lux, 2003): 
A country with an acute need of new housing supply cannot afford to experiment with hybrids of new and old practices ... [but] so long as the government is occupied by problems or connected with paternalistic old practices, it does not have either the political will or the time to prepare and introduce new, more effective/efficient subsidies. (p. 264)

Hence, keeping or simply decentralising such old practices would not solve the problem created under the new economic regime as interest groups would lobby the central government to continue to retain the inefficient old system.

In sharp contrast to the 'big-bang' approach in Eastern Europe, China adopted a much more cautious pace in her housing reform. Similar to her counterparts in Eastern Europe before the reform, the overwhelming majority of housing in cities in the early 1980s were publicly owned ( 82 per cent) (by work units, 54 per cent and by local government, 29 per cent) and the remaining 18 per cent privately owned housing was of poor quality, most it needing redevelopment (Wang, 2007). Housing reform in China was formally kicked off in 1980 with a series of small-scale experimental projects in medium size cities, apparently wanting to contain the associated risk. With results of the experimental projects gaining momentum, full scale housing reform was promulgated in 1988 to sell state housing to sitting tenants at a deep discount (Wang \& Murie, 1996).

More fundamental changes were brought forward in 1994 in which the responsibility of the state in housing would be shifted to individuals. Compulsory savings for housing, the Housing Provident Fund which was modelled on the Singaporean system, with contributions from both employees and their employers, was installed to enhance the purchase capacity of ordinary citizens. At the same time, to offset the envisaged turbulence of a newly created market, a dual housing provision will be established. Affordable housing (jungji shiyong fong) was introduced alongside commodity housing, with the latter sold at market price to ordinary citizens whilst the former targeted at middle to lower income households with support from the central government via loans or free allocation of land. Despite large-scale privatisation of public housing in the 1990s which made the majority of urban dwellers homeowners towards the end of the 1990s, the housing market in China was still sluggish. As the state continued to provide housing to their employees (which subsequently could be bought at deep discount as sitting tenants), the incentive of individuals to mobilise their own resources to acquire housing in the market was thus limited and most newly built commodity housing has to be absorbed by the old welfare housing system (Wang \& Murie, 1996). It is under such context that new housing policies were introduced in 1998 to put an end to in-kind provision from work units and all housing benefit would be 'monetarising' as part of the wage package of employees. The market was then the only venue in which housing need of urban dwellers can be solved, either by renting or buying. The support for house buying was also being enhanced by a more comprehensive housing finance system with funding from the Housing Provident Fund and the banking system. Such a move proved to be effective in stimulating mortgage lending and consequently the home ownership market-in 2003 over 82 per cent of households in cities owned their homes and most public housing was sold to sitting tenants (for instance, in Beijing 87 per cent of public housing was sold) (Wang, 2007).

Yet the promotion of home ownership has boosted the demand and, unsurprisingly, also created an overheated housing market in late 1990s and early 2000s. For instance, Shanghai's house prices have doubled during 2002 and 2004 which produced an outcry 
among middle to low-income households who found housing well beyond their means (Wang, 2007). Such affordability problems should have been pre-empted, at least partially, by the affordable housing schemes in the 1994 housing reform. Yet, most of the affordable housing projects have ended up in a fiasco. The concern for profit margin (so that big and luxury 'affordable' apartments are constructed) and corrupt administrative control (loose income screening) has made more eligible lower middle income households unable to afford the 'affordable' housing and most of such housing units ended up with speculators who were able to make windfall profits on the immediate resale (which was not permitted) (He \& Jin, 2007). This reflects the urgency in balancing the concern for economic efficiency (to develop affordable housing units at the cheapest cost while selling them off as quick as possible) to targeting efficiency (equity in distribution and subsidy) (Wang, 2007).

More recently, restructuring of China's economy as a result of its integration into the global economy have brought along income polarisation and hardship among low-skilled workers and workers who were being layoff. The Ministry of Construction issued a decree in 1998 to facilitate local governments to develop low-cost rental housing (lianzu fang) for low-income families (Wang, 2007). However, very few cities have implemented such policy and amongst cities that have such provision, only a small group of the very poorest families were covered (Wang, 2007). To cope with the increasing demand for social low-cost housing, a new decree was issued in 2007 which reiterates the responsibility of local government in the provision of social housing and calls for an expansion of its target coverage (Ministry of Construction, China, 2007, Decree 162). In order to secure the financial support for low-cost housing, the decree also obliges local government to earmark all the net profit generated by the Housing Provident Fund as well as not less than 10 per cent of the net income from land sale for the development of low-cost social housing.

\section{Creation of Housing Market in Vietnam}

Before Doi Moi was introduced in 1986, housing production in Vietnam was monopolised by the state. Housing was distributed exclusively to state employees, via the work units, as a supplement to the low level of wages at a very low rent level which was even not enough to cover the cost of maintenance (Luan \& Nguyen, 2001). Yet, not only were people outside the state sector excluded from state housing, they were also prohibited from building their own homes. However, owing to the lack of state funding, it is estimated that only 30 per cent of government employees stayed in state provided housing in the early 1990s whilst the rest had to resort to their own means in solving their housing needs (Luan \& Nguyen, 2001).

Housing reform began in 1986 under the general premises of Doi Moi. Provision of rental housing for state employees was terminated in 1992. From 1993 onwards, rents of state-owned housing were raised and this was accompanied with an adjustment of the salaries of state employees in order to offset the impact of rent increases. The new direction of housing policy then was to stimulate housing production and to establish a viable housing market for the improvement of living space and housing quality. Important moves include the establishment of the legal basis for land and housing ownership and transaction as well as the marketisation of the building materials industry. A new Land Law came into effect in 1993 which consolidated the land use right of individuals as well as the right to sell and exchange. A governmental decree (Decree 61/CP, 1994) was also issued which specifies the administrative procedure in the trading of housing. With the 
creation of a market for housing, the state's involvement in housing production has been transformed from a direct provider and financier, to market player and enabler. The private sector was expected to take up a bigger share in the production of housing which would be supplemented by public-private partnership.

To further boost the production of housing, the ban on self-help building activity was lifted at the end of the 1980s. Local governments, via various state institutions, began to allocate land to state employees for self-build activities. Housing production was further boosted in the late 1990s by a series of directives in encouraging investment by large developers, such as exemption of land premium and tax breaks. Former state housing production units, which have been marketised, became major players in the housing market. At the same time, investments by foreign developers were also encouraged. They were granted favourable land lease schemes, tax breaks and an increased level of autonomy in running their projects. This resulted in a housing boom in many urban cities of Vietnam. In Hanoi, for instance, 300 000-400 000 square metres were added in the early 2000s and more than 1 million square metres floor area were added to the stock each year after 2003.

There has been a clear shift in housing production by sector from the 1990s into the 2000s. During the 1990s the majority of new housing production was carried out by private individuals on a small scale. Yet from 2001 onwards, the bulk of housing production in Hanoi are larger scale housing projects built by both public and private developers. More than 70 large housing projects were completed by the end of 2004, most of them by state and municipal housing companies. Table 1 shows the change in housing production by sectors from 1999 to 2004.

Privatisation of the state-owned housing stock (termed 'socialisation of state housing' in Vietnamese) was introduced in 1994. Despite the introduction of a deep discount and several additional incentive schemes, the response was lukewarm. It was only after 2002 that the demand picked up. Up to 2006, 12 years after the programme was introduced, only half (58 per cent) of the state housing stock was sold to sitting tenants (VietNamNet, 2007). At the same time, from the late 1990s to 2005 the housing ownership structure in the urban areas has clearly been shifted from predominant state sector to private ownership.

Table 1. New housing floor areas by capital source in Hanoi, 1999-2004

\begin{tabular}{|c|c|c|c|c|c|}
\hline $\mathrm{m}^{2}$ & 1999 & 2000 & 2001 & 2002 & 2003 \\
\hline Planned area & 400 & 450 & 620 & 720 & 900 \\
\hline Completed area & 416 & 597 & 843 & 1036 & 1284 \\
\hline \multicolumn{6}{|c|}{ Breakdown of completed area } \\
\hline Central construction ${ }^{\mathrm{a}}$ & 36 & 82 & 155 & 335 & 541 \\
\hline Local construction ${ }^{\mathrm{b}}$ & 380 & 515 & 688 & 701 & 743 \\
\hline \multicolumn{6}{|c|}{ Breakdown of local construction } \\
\hline Local budget & 3 & - & 85 & 111 & 162 \\
\hline Other capital & 15 & - & - & - & - \\
\hline Joint venture capital & 76 & 105 & 178 & 175 & 221 \\
\hline Self-building by people & 286 & 410 & 426 & 415 & 360 \\
\hline Achievement ratio ${ }^{c}$ & $104 \%$ & $133 \%$ & $136 \%$ & $144 \%$ & $143 \%$ \\
\hline
\end{tabular}

Source: Hanoi Statistical Yearbook (2002, 2003, 2004).

${ }^{a}$ Housing construction by companies or institutions related to central agencies.

${ }^{\mathrm{b}}$ Housing construction not related to central agencies.

${ }^{\mathrm{c}}$ Achievement rate-completed area as a proportion of planned area. 
Table 2. Housing ownership in Hanoi

\begin{tabular}{llccccc}
\hline & & \multicolumn{5}{c}{ Share by ownership types (\%) } \\
\cline { 3 - 6 } & & $\begin{array}{c}\text { Privately } \\
\text { owned }\end{array}$ & $\begin{array}{c}\text { Rented from } \\
\text { government }\end{array}$ & $\begin{array}{c}\text { Rented } \\
\text { from others }\end{array}$ & $\begin{array}{c}\text { Collectives } \\
\text { or religious } \\
\text { organisations }\end{array}$ & Others \\
\hline 1989 & Urban district & 47.3 & 48.1 & 0.0 & 2.2 & 2.4 \\
1999 & Hanoi total & 76.3 & 18.3 & 3.8 & 1.1 & 0.5 \\
& Urban districts & 63.1 & 29.7 & 5.0 & 1.6 & 0.6 \\
2005 & Rural districts & 92.0 & 4.8 & 2.4 & 0.6 & 0.2 \\
& Hanoi total & 91.5 & 3.8 & 0.4 & 2.8 & 1.5 \\
& Urban districts & 91.3 & 4.4 & 0.3 & 3.2 & 0.8 \\
& Rural districts & 95.5 & 1.7 & 0.4 & 2.1 & 0.4 \\
\hline
\end{tabular}

Note: Percentages sum to $100 \%$ across the row.

Source:

Figures for 1989—Vietnam Census and sample results of Housing Survey, 1990.

Figures for 1999_-Population and Housing Census Vietnam 1999.

Figures for 2005-HAIDEP HIS, 2005.

Since the late 1980s, the share of private housing had increased from 47.3 per cent in 1989 to an overwhelming proportion of 91.5 per cent in 2005 (Table 2).

Further adaptation to the market mechanism came with the new Land Law in 2003 which terminated the privilege of developers in land premium exemption, which had been employed by local governments in exchange for a proportion of the completed units for their redistribution. The new system from 2004 onwards put an end to the barter system. Revenue collected by local governments in land premium, which would then be set at market price, would be used to fund the development of social housing. The Real Estate Law, enacted in 2006, further boosted the housing market with the introduction of a comprehensive legal framework for land and housing transaction, leasing of land and property, real estate services and pricing of real estate.

\section{State and Market Interactions}

\section{Mediating Role of the State}

Despite the end of rental housing allocation to state employees in 1992, the state still continued to provide housing for state workers. It was made possible by the barter system (mentioned in the previous section). Private developers were required to surrender 20 per cent of the housing site, or 30 per cent of completed floor space to the local government which would then be resold to "state employees and salaried workers in other economic sectors who are in need of housing" (Decision 87/2004/Q\$-UB). Nominated buyers of such housing units could enjoy a discounted price (at cost) and favourable repayment terms (mortgage was then not the norm of house transaction). Developers were compensated with reduced (or even exemption of) land premium and tax breaks. In projects initiated by the local government, developers could even be directly subsidised for infrastructure development on the behalf of local governments. The government also intervened in controlling the price of new production to ensure that they were affordable to state employees. For instance, in Hanoi, developers were required to sell 50 per cent 
of floor areas in high rises they developed (or 25 per cent in villas) at price levels fixed by the city (Decision 76/2004/QD-UB).

With the enactment of the new Land Law in 2003 which obliged the charging of land use right at market price, local governments could no longer get 'cheap' housing for their employees. In order to secure enough housing for state employees, a new directive was issued in 2006 (Decision 153/2006 QD-UBND) which requires developers to sell 20 per cent of the developed site or 30-50 per cent of the completed units either to the local government or directly to state employees nominated by the local government. Yet the transactions have to be at market price. However, it is still too early to assess the impacts of this directive as no transactions under the new directive have been made.

In its path to market reform, the Vietnamese state has withdrawn from direct housing construction and subsidies as well as gradually faded out the dual price systems. Yet the housing boom has also created an overheated housing market (for instance, residents of Ho Chi Minh City queued up for the whole night for new dwelling units) but most of such new production ended up in the hands of speculators who were well connected to the developers. The state is under political pressure to secure on the one hand housing resources for its employees whereas on the other hand to curb housing speculation. Hence, the state has to continue its high profile intervention in the housing market in channelling housing resources in the market to state employees at a cost they can afford. Capital gains tax may also have to be contemplated in order to curb speculation (DoThi.net, 2007).

\section{Role of the State in Urban Redevelopment}

In urban redevelopment, the state adopts a facilitating role but reframes itself from direct involvement. Private developers are allowed to initiate urban redevelopment projects and they are entitled to indirect subsidies like loans from the Municipal Investment and Development Fund at low interest, tax breaks and other forms of interest subsidies. Direct subsidies like reduction of land premium and even cash subsidies can be granted to projects with low profit and high social impact. Yet, developers are responsible for the compensation and relocation of residents.

An apparent contradiction in urban development is the conflict between social and economic needs. For instance, the plan directive in Hanoi intends to control building height in the inner city in order to contain the growth of population density. However, this is obviously at odds with the financial viability of redevelopment in which developers need to build more units in high rises in order to offset the high cost of relocation and compensation. Constraints imposed by the plan directive thus held up many redevelopment projects on the drawing board. Pressing demand for an acceleration of urban development has pushed the central government to loosen the control by allowing local government the flexibility to adjust their planning directive for cases where there is burning need for redevelopment (Decree 34/2007/NQ-CP).

Yet by far the most controversial and baffling issue in urban redevelopment centred on the requests from ground floor occupants who often utilise their ground floor units for commercial activities. Under the redevelopment directive of Hanoi municipality, they will only be offered upper floor units as compensation, partly owing to the plan in reassigning the ground floor for open and communal space and partly because ground floor units are important income sources for the municipality. This triggers intense resistance from ground floor business operators who regard themselves losing out both in their investment 
of properties (big value difference between upper and ground floor units) as well as future income from their business. Complicating the issue further is whether the public space they illegally enclosed previously for their business should be counted towards the assessment of compensation. Incidents of intensive protests did occur in some areas which held up the process of redevelopment. Yet unlike some cities in China in which resistance against redevelopment was brutally suppressed by the state, the Vietnamese state is more tolerant and the use of force for evacuation is nearly unheard of.

\section{Problem of Affordability and Inequality}

The quest for high profit has driven developers, private and public alike, to squeeze into the higher end market. For instance, in Hanoi, the price of new apartments can reach US\$100 000-200 000 per flat which is 10-20 times the annual income of an average worker. Hence, only a small group of wealthy middle class are able to afford such apartments. At the same time, housing inequality has also exacerbated. Households can live in congested homes as low as $2 \mathrm{~m}^{2}$ per person and in sharp contrast, wealthier households can enjoy living space as big as $10 \mathrm{~m}^{2}$ per person and this gap is increasing (Nguyen, 2005). Although developers are obliged to earmark a certain proportion of their newly produced units for state employees (Decision 87/2004/Q\$-UB), the high cost of down payments (e.g. up to 70 per cent of the house value in Hanoi) they required, apparently wanting to recover the capital upfront amidst an underdeveloped housing finance system. This has made low-income workers out of reach for new flats. Even early schemes of low-income housing (built before 2003) requested a high down payment of 50 per cent of the house value (vietbao.vn, 2003). This has been reduced to 30 per cent in recent years to ease the capital constraint of home buyers. Recently there are suggestions to lengthen the repayment to between 25 and 40 years in order to reduce the income burden of home buyers and brings the repayment to income ratio to within 10 per cent (laodong.com.vn, 2008).

As mentioned earlier, the local authority required housing developers to surrender a proportion of their newly produced housing units (Decision 87/2004/Q\$-UB). These are to be sold at 'favourable price' or 'priority price for state employees'. ${ }^{1}$ However, as house prices are high for most state employees (at US $\$ 50000$ per unit) and a down payment of 70 per cent is requested, more than one-third of those who were offered to buy did not take up the offer (DoThi.net, 2006c).

As public rental housing has not been made available, average and lower income groups have had to rely on private renting. Yet the private rental sector is a neglected and largely unregulated sector with poor quality housing stock and tenants who are predominantly immigrants, the majority of whom are poor or without legal residence status. These socially vulnerable private tenants also enjoy neither tenure security nor rent protection.

Privatisation also exacerbates the problem of housing inequality. The privatisation policy, particularly the sale of public housing to sitting tenants at deep discount, benefited high ranking government officials and war veterans many of whom are well situated both economically and politically. With their social and political connection, they were often able to acquire better housing in the newly created housing market at a favourable price whilst at the same time earned windfall profit by reselling their old public housing. It was the younger households and low-income workers, either not eligible for the home ownership incentives or unable to afford home ownership, who were left behind in the old housing as tenants (Tran \& Dalholm, 2005). 


\section{Ambivalence towards Market Reform}

Despite the fact that market reform was well received in Vietnam, there is also considerable ambivalence expressed by both ordinary citizens and government officials. For instance, a survey in early 2002 on public views towards the opening up of the national economy (Duckett $\&$ Miller, 2006) reveals that an overwhelming majority (76 per cent) of the general public in Vietnam thought that market reform brought advantage to the country (against 5 per cent that thought it did not). Yet, it was the same group of respondents who would also demand more government intervention in the market economy, 69 per cent of them thought that the government should be more interventionist whereas only 10 per cent thought it should not.

Painter (2006) made a similar observation on state pay reform - "[state pay reform] is not just connected with marketisation but also, somewhat paradoxically, with a strategy to reassert state control and legitimacy through realigning official policy so as to corral local practices" (p. 341). Although institutional and organisational adjustments have been introduced to rationalise the changing state-market interaction, such changes are far less profound than what they suggest at the surface. The party state would strive hard to make sure stability is maintained while the transition can be largely under control or at least being contained, together with the business interests being generated by the reform process (Painter, 2005). Unlike her counterparts in the former Soviet Union and Eastern Europe, market reform in Vietnam is less driven by the ideology to embrace capitalism or by the political pressure imposed by a newly introduced democratic system as in those countries. The reform has been compelled by the pragmatic need to tackle the economic crisis and hence the pace of reform was more cautious and conservative. Pham (2003) compares market reform in China and Vietnam and remarked that Vietnam's policy on the privatisation of state-owned enterprises appears to be less embracing and more or less adopted a stop-and-go approach of retaining the state sector as a 'guiding component'. Such backlash is well demonstrated in the housing reform and the provision of state housing, which will be further elaborated in the sections that follow.

\section{Public Housing Revitalised}

\section{Housing for the Needy}

The problem of affordability and growing housing inequality expose the inadequacy of the housing market in solving the housing need of the disadvantaged groups. Public opinions begin to focus on the shortage of public housing for the needy as a major cause of housing problems in urban areas, especially among low-income households and workers in large industrial zones (Ministry of Construction, 2005). The shortage of rental housing for students and migrant workers is particularly acute in Hanoi and Ho Chi Minh City which drives up rents in the private rental sector.

The new Housing Law that came into effect in 2006 clearly marks a renewed intention of the state to develop public housing for civil servants. Two categories of public housing are specified: 'social housing' and 'service housing'. Whilst the latter is staff quarters for state/municipal employees tied to their employment, the former (either rental or owner occupied) is targeted at low-income employees who do not have adequate housing (Article 53). Incentives are reinstated for developers to develop social housing in the form of land premium reduction or tax breaks and even direct state subsidies if they also provide infrastructure development for the social housing projects. The urgency of housing for 
workers in large industrial zones, which are rapidly expanding (149 zones have been planned among which 109 are in operation in 2006), is the focus of concern. Yet, only 20 per cent of workers in such areas have decent dwellings whereas the rest of them have to reside in private rental dwellings in very poor conditions (Ministry of Construction, 2005).

\section{Ambitious Social Goals and Poor Implementation Capacity}

The Vietnamese government has a clear ambition to provide housing for the socially disadvantaged groups - the poor ${ }^{2}$ and people in the 'policy' category. 'Policy housing' is developed for the latter group which is funded fully from the state budget and targeted at war invalids, 'senior revolutionaries' (people who joined the revolution before 1954) and the family of war heroes. On the other hand, poor and disadvantaged households can get help from the 'solidarity housing' scheme which is only partially supported by the state. Such schemes are implemented by local communities and part of the funding has to come from humanitarian organisations and individuals.

The state also initiates housing projects, 'housing for the poor' scheme, for people on state benefits. ${ }^{3}$ Built with the state budget, apartment housing units were either rented or on a rent-to-buy arrangement to eligible households. Yet, such experimental housing for the poor was quickly found to be a failure. The poor administrative capacity of local government has not been able to enforce the resale embargo. Most such housing units were resold, in less than one year of occupation, to ordinary buyers for a profit. Similar outcomes were also observed in several other policy housing projects in which only a few original beneficiaries still stayed. At the same time, incentives were also offered by the state to the private sector to develop housing for low-income households. Yet publicprivate partnership for low-income housing appears to be largely ineffective. On the one hand, such incentives are not attractive enough for private developers whereas on the other hand developers are also deterred by the complicated bureaucratic procedures of investment approval they have to undergo (DoThi.net, 2006b).

A similar fiasco was also witnessed in 'housing for the low income' scheme which was state-developed owner-occupied housing for state employees. Intended to be sold at "noprofit' price to households on low income, most of such housing units were beyond the reach of low-income state employees as buyers were required (e.g. in Hanoi) to pay a down payment at 70 per cent of the selling price (and the rest was to be paid by instalments over 20 years). Hence such housing units ended up in the hands of whoever could afford them. This obviously defeats the stated policy objective. Even worse was the loophole in the system that enabled speculators to defy the resale embargo and make windfall profits from the gap between the discounted and market price on reselling the housing units which they should not have been allocated in the first place. Corruption and irregular practices in allocation have obviously offered a shortcut for the speculators to exploit the cracks in the system.

Although housing for the low income is considered an important goal of housing development, there is no consensus on who should be the low-income households. Some argued for the average income (VND 825000 (US\$51) per month in Hanoi in 2006) (Do, 2006) to be the threshold whilst others suggested instead a low level of VND 500000 (US\$31). In addition, whether only the 'deserving' poor (people with contribution-state employees, workers in large industrial zones, etc.) be included is also contentious (Nguyen, 2006). Lack of consensus in defining the target group of poor households has slowed the implementation for the policy of housing for the poor. 


\section{Old Hierarchy Returned}

From the start of the housing reform, state employees have all the way been gainers of the new policies. Not only did housing privatisation, with deep price discount, benefit state employees in purchasing their dwellings, state workers continue to be the main beneficiaries of recent housing initiatives. For instance, new housing units which the municipalities acquired from private developers are redistributed to state workers and their purchasing power is further enhanced by housing loans from the state. In 2006, the Housing Development Funds were introduced in Hanoi and Ho Chi Minh City which offer low interest loans up to 70 per cent of the value of the house, yet only state employees (subject to other criteria) are eligible (DoThi.net, 2006a). Likewise, Hanoi city intends to develop, up to the year 2010, a limited social rented housing stock for people who cannot afford to buy. Yet such social housing is targeted only to "young households, newly graduated professionals and workers getting payment from the municipality budget" (Nguyen, 2006) but excludes workers on contract as well as seasonal workers and workers who are unemployed from the housing system.

The new Housing Law, issued in 2006, even openly favours state employees. Targets for social housing in the new housing is restricted to "specific categories of employees" of "low-income employees that do not have adequate housing" which are then further narrowed down to "state employees, officials, government staffs, military officers, professionals in the defence forces" and a limited section of workers in the private sector: "workers working in the economic zones, industrials areas, production areas, high tech areas, and other groups as specified by Governmental decrees" (QD 76/2004/QD-TTg, Article 53). As such, it excludes low paid workers in the private sector, people engaged in small family businesses, those who do not have regular work and the unemployed. Hence, in sharp contrast to the system of social housing in many other countries which targeted people on low income, state employees as the main targets of social housing in Vietnam seem not to be highly justified. Although the average income of state employees is somehow lower than their counterparts who work for projects with foreign investment, they are considerably better off than those who work in the private sector (Table 3). State sector jobs are also relatively more stable vis-à-vis their counterparts in the private sector. A more convincing explanation of setting state workers as the target of social housing is the regression to the old way of responding to political demand of loyal supporters of the state albeit by means of resource distribution has been substantially altered. It also shows that the reform is still based on the old ideology and supports the old hierarchy.

Table 3. Income of workers in various sectors in Vietnam 2002, 2003

\begin{tabular}{lll}
\hline & Workforce & Average income/month \\
\hline State sector & 2353767 & VND 1 479000 (US\$92) \\
Private sector & 1943188 & VND 1044000 (US\$65) \\
Sector with foreign investment & 786908 & VND 1 900000 (US\$119) \\
Hanoi City & 669229 & VND 1473000 (US\$92) \\
Ho Chi Minh City & 1155495 & VND 1819000 (US\$114) \\
\hline
\end{tabular}

Note: US\$1 roughly equals VND 16000 as of December 2007.

Source: Vietnam Labour Union, cited in Ministry of Construction (2005). 


\section{Concluding Remarks: State and Market in Transitional Vietnam}

Similar to other transitional economies, housing stands at the forefront of the economic reform in Vietnam. Owing to its close link with people's daily life, easy transfer of ownership and the multiplier effect it generates on the economy, privatisation of housing has become a handy symbol of economic reform. Vietnam also clearly demonstrated its initial determination to engage a fully fledged reform in the housing sector. On the supply side, it withdrew from direct production of housing fairly early in the reform. This was not a difficult task for the Vietnamese state as housing production was already very low before the reform. State housing organisations were soon turned into market operators and they had to compete with other newly established market players. Land was released for private or quasi state developers for the construction of market housing for sale. Lifting of the ban on private construction also instantaneously boosted self-build activities. On the demand side, state housing was put up for sale to sitting tenants at a deep discount. The state has been picking up fast in making new laws and regulations on property rights and property transactions that are necessary for the market to develop and operate. Outcomes of the housing reform also appear to be encouraging. Both housing production as well as home ownership rate have been steadily on the increase. Secondhand housing transactions were also beginning to take off which indicates that the creation of a fully operating housing market is on the way.

Yet, masked by the apparent 'success' of housing privatisation is the continuation of the old socialist way of housing provision. Under the reform policy, the state has to relinquish direct involvement in the production of housing and privatised state construction enterprises. But former state production units that have been marketised still maintain substantial linkages with their former mother state organisations and usually have advantage in getting state projects. This produces a negative impact on competition in the market. On the consumption side, private developers were asked, before 2003, to surrender for free a certain proportion of the completed housing units to local governments for distribution to state employees in exchange for the reduction of land premium. Whereas after the new Land Law in 2003 in which the system of land leasing premium was formalised, local governments would buy from private developers at prevailing market price. Experience from China in the mid-1990s has suggested the negative impact such practice would have on the long-term viability of the housing market, albeit Vietnam is less reliant on the state in providing housing for their employees. It nevertheless illustrates a mistrust of the state in the ability of the market in solving the housing problem of the already relatively better off state workers who at least have a moderate but stable income.

However, compared to China, Vietnam displayed, fairly early in the reform stage, a clear social ambition in addressing the housing need for the socially disadvantaged. Yet programmes of social housing turned out to be twisted by lobbies of vested interest factions as well as pragmatic administration considerations. Despite the widespread problem of housing affordability for the low income and those who are out of work, most of the 'low-income' housing projects are for sale and charge a high level of down payment (up to 70 per cent of the housing price) which is beyond the reach of most low-income families. At the same time, targets of the new rental public housing (which responds to the demand for housing of the poor) are limited to state employees - an apparent move to secure the loyalty of the supporters of the state. It also illustrates that housing reform in Vietnam is based on the old values and built on the old political hierarchy. Apparently driven by pragmatism but not an ideological 
commitment, market reform in Vietnam has, from the start, only half-heartedly been embraced by the state and ordinary people alike. The legacy of the socialist system and the resistance to the reform have back-lashed and the old ways of working have been restored albeit with a substantial reconfiguration in appearance.

Hence, despite the fact that the paper only focuses on some special aspects of the Vietnamese housing reform such as the struggle between market aspiration and social concern, it suffices to unveil the conflicts between dedicated political goals and poor implementation capacity, as well as how the old value still underpins the housing reform, contributing to the restoration of the old social hierarchy. These issues are, however, shared by many housing reform processes of transitional economies - the changing yet confusing role of the state, ambivalence in the creation of the housing market, and issues of affordable housing and social equity.

\section{Notes}

1. In Hanoi, a list of state employees qualified for housing priority is formulated by different state institutions to send to the local housing authority who provide them with the chance to buy new housing at 'non-profit' or 'favourable' price.

2. The poor people refers to those with a monthly income equal or lower than VND 260000 (US\$16) per person per month.

3. People who are qualified to get monthly income subsidies from the government via the Ministry of Labour, War Invalids, and Social Affairs.

\section{References}

Do, N. K. (2006) Mot so van de ve xac dinh nguoi co thu nhap thap va tinh trang nha o cua nguoi co thu nhap thap tren dia ban thanh pho Ha noi [Some problems in defining the low incomes and the housing situations of the low incomes in Hanoi]. Paper presented at the seminar on Solving the Problem of Housing for the Low Incomes in Hanoi-Current Situations and Solutions, People's Committee of Hanoi, September 2006, pp. $32-35$

DoThi.net—News Daily (2006a) Qui phat trien nha o cho nguoi thu nhap thap: rat it nguoi duoc vay [Housing development fund for the low income: very few can borrow]. DoThi.net, 24 February. Available at http:// dothi.net/News/Home/ (accessed November 2007).

DoThi.net—News Daily (2006b) Nha re chi co tren giay [Low cost housing remains on paper]. DoThi.net, 25 May. Available at http://dothi.net/News/Home/ (accessed November 2007).

DoThi.net—News Daily (2006c) Hà Nội 'ế' nhà u'u đãi [Priority housing in Hanoi remains unsold]. DoThi.net, 23 November. Available at http://dothi.net/News/Tin-tuc/Thi-Truong/2006/11/3B9ACE68/ (accessed June 2008).

DoThi.net—News Daily (2007) Giá căn hộ chung cu' Hà Nội: Nóng lên tù'ng ngày [Price of apartments in Hanoi: all the more heated]. DoThi.net, 18 October. Available at http://dothi.net/News/Home/ (accessed November 2007).

Duckett, J. \& Miller, W. L. (2006) The Open Economy and its Enemies: Public Attitudes in East Asia and Eastern Europe (Cambridge: Cambridge University Press).

Gray, C. W. (1996) In search of owners: privatization and corporate governance in transition economies, World Bank Research Observer, 11(2), pp. 179-197.

Hamilton, I. (1999) Transformation and space in Central and Eastern Europe, The Geographical Journal, 165(2), pp. 133-144.

He, W. D. \& Jin, P. L. (2007) Affordable housing policy should switch back to its basics, Urban Development, 11, pp. 61-62.

Hegedüs, J. \& Tosics, I. (1996) The disintegration of the East European housing model, in: D. Clapham, J. Hegedüs, K. Kintrea \& I. Tosics (Eds) Housing Privatisation in Eastern Europe (Westport, CT: Greenwood Press). 
Hegedüs, J. \& Tosics, I. (1998) Transition and social sustainability in post socialist urban systems: new challenge in the restructuring process of Central-Eastern European metropoles. Paper presented to the conference "Housing Futures, Renewal, Sustainability and Innovation". Cardiff, 7-11 September 1998.

Laodong.com.vn (2008) Hỗ trọ’ nhà ò' cho ngu'ò’i có thu nhập thấp, đối tu'o'ng chính sách [Housing support for the low income and policy category]. 22 May. Available at http://www.laodong.com.vn/Home/kinhte/2008/ 5/89583.laodong (accessed June 2008).

Luan, T. D. \& Nguyen, Q. V. (2001) Socio-economic Impacts of 'Doi Moi' on Urban Housing in Vietnam (Canada: Social Sciences Publishing House).

Lux, M. (2003) Efficiency and effectiveness of housing policies in the Central and Eastern Europe countries, Journal of European Housing Policy, 3(3), pp. 243-265.

Ministry of Construction (2005) Bao cao tong quan de tai NCKH Nghien сии Giai phap Khuyen khich Phat trien Nha o cho thue [Report of a Scientific Research Project on Solution to Encourage Rental Housing Development], (Housing Department, Ministry of Construction).

Ministry of Construction, China (2007) Low cost housing protection practice. Decree 162, 26 September. Available at http://www,gov,cn/ziliao/flfg/2007-11/27/content_816644.htm (accessed December 2007).

Nguyen, D. B. (2005) Chinh sach nha o cua thanh pho Ha noi den nam 2010 [Housing policy of Hanoi City to the year of 2010]. Paper presented at the seminar on Housing and Management, Institute of Architectural Research, Hanoi, May 2005.

Nguyen, H. A. (2006) Mot so kinh nghiem va ke hoach trien khai du an thi diem dau tux ay dung nha o phuc vu nguoi thu nhap thap tai dia ban thanh pho Ha noi [Some experiences and plans to implement experimental investment in housing for the low income in Hanoi city]. Paper presented at the seminar on Solving the Problem of Housing for the Low Incomes in Hanoi-Current Situations and Solutions, People's Committee of Hanoi, September 2006, pp. 53-56

Painter, M. (2005) The politics of state sector reforms in Vietnam: contested agendas and uncertain trajectories, The Journal of Development Studies, 41(2), pp. 261-283.

Painter, M. (2006) Sequencing civil service pay reforms in Vietnam: transition or leapfrog? Governance: An International Journal of Policy, Administration, and Institutions, 19(2), pp. 325-347.

Pham, T. (2003) The Chinese economic model: some tentative conclusions for Vietnam, in: B. Tran-Nam \& C. D. Pham (Eds) The Vietnamese Economy: Awakening the Dormant Dragon (London and New York: RoutledgeCurzon).

Pichler-Milanovich, N. (2001) Urban housing markets in Central and Eastern Europe: convergence, divergence or policy 'collapse', European Journal of Housing Policy, 1(2), pp. 145-187.

Renaud, B. (1995) The real estate economy and the design of Russia housing reforms, Part I, Urban Studies, 32(8), pp. 1247-1264.

Stephens, M. (2005) A critical analysis of housing finance reform in a 'Super' home-ownership state: the case of Armenia, Urban Studies, 42(10), pp. 1795-1815.

Tran, H. A. \& Dalholm, E. (2005) Forward owners, neglected tenants: privatisation of state owned housing in Hanoi, Housing Studies, 20(6), p. 897.

Tsenkova, S. \& Turner, B. (2004) The future of social housing in Eastern Europe: reforms in Latvia and Ukraine, European Journal of Housing Policy, 4(2), pp. 133-149.

Vietbao, vn (2003) Daily News. 19 April. Available at http://vietbao.vn/Kinh-te/4-du-an-nha-o-cho-nguoi-thunhap-thap-Ha-Noi/10815267/175/ (accessed June 2008).

VietNamNet (2007) Đã bán hết 58\% tống quỹ nhà thuôc Sò’ hũ’u NN [58\% of the state owned housing stock has been sold]. VietNamNet, 28 March. Available at http://www.vietnamnet.vn/ (accessed November 2007).

Wang, B. (2007) A discussion on the breakthrough and enhancement of new monitoring measures on real estate policy, Modern Scientific Management, 10, pp. 70-72.

Wang, Y. P. (2007) From socialist welfare to support of home-ownership: the experience of China, in: R. Groves, A. Muriue \& C. Watson (Eds) Housing and the New Welfare States (Aldershot: Ashgate).

Wang, Y. P. \& Murie, A. (1996) Housing Policy and Practice in China (London: Macmillan). 